\title{
CHARLES ERNEST BAZELL
}

When Professor C. E. Bazell died in April of last year at the age of 75, having suffered from leukaemia for some time, his recent interests had included a book on intentionality by the philosopher $J$. R. Searle and a book defining a completely new 'Situation Semantics' theory by the two American philosophers J. Barwise and J. Perry. ${ }^{1}$ This continuing commitment to current arguments within the discipline gives I think the most accurate reflection of his total and unstinting absorption in the subject he had worked in all his life.

When his academic profession began, Linguistics in England was only studied under the umbrella of either Comparative Philology or Phonetics; and Bazell himself falls into the former category. His first reputation was as a philologist (he was a fellow of Magdalene College of Oxford from 1934-1942). During the interwar years, Linguistics became established in the United States as an academic discipline in its own right, and typically, Bazell's own interests expanded with the forefront of the field. In 1942 he went to Istanbul under the auspices of the British Council to take up a Chair of English Language, a chair which from 1944 became also a Chair of General Linguistics. While at Istanbul, he wrote his one seminal book Linguistic form (Istanbul Press, 1953) and a considerable number of articles, all of which display a commitment to working within the current field of structural linguistics even while being sharply critical of much of its practice. In the immediate post-war years, Linguistics became established as a separate discipline by Professor J. R. Firth, and in 1957 Bazell came back to England to take up the Chair of General Linguistics at SOAS, a post he held until his retirement in September 1977. In that year, Noam Chomsky's revolutionary Syntactic structures ${ }^{2}$ was published, and it is typical of Bazell that he noticed immediately that 'Linguistics will never be the same' and set up a correspondence with Chomsky in response to having read his work. ${ }^{3}$ From that time on, Bazell's linguistic interests always included a concern with the ever expanding articulation of that new paradigm, an interest which continually evolved as the subject developed right up to the time of his death.

To the linguistic world in general, Bazell takes a place in linguistic history as one of the foremost structural linguists outside the United States. In a volume of readings in Structural Linguistics largely devoted to work in Structural Linguistics in Europe, ${ }^{4}$ the number of Bazell's articles exceed even those of Trubetzkoy and Jakobson, both acknowledged masters in the subject. Bazell was not a leader of the field in the sense of establishing his own paradigm, but his articles of this period display him as a first-class theoretical linguist and also a man of shining good sense, with an ability both to work within a paradigm while simultaneously standing back from it and reflecting, often critically, on the theoretical perspective it creates. He combined a broad knowledge of languages with an exclusiye concern with explanation of the phenomenon of language itself, explanation which may, indeed must, include the most familiar combinations in the most familiar languages. Thus one paper ${ }^{5}$ includes references to, North Chinese (Mandarin), Old Slavonic, Tibeto-Burman dialects, Greek, Finnish, Hungarian, Russian, German and Turkish (including Osmanli Turkish)

${ }^{1}$ Searle, J. Intentionality, Cambridge, 1983; Barwise, J. and J. Perry. Situations and attitudes, Cambridge Mass., 1983.

${ }^{2}$ Chomsky, N. Syntactic Structures, The Hague, 1957.

3 Newmeyer, F. Linguistic theory in America, London, 1980.

4 Hamp, E. et al. (ed.) Readings in linguistics II, Chicago, 1966.

5 'On the neutralisation of syntactic oppositions' Travaux du Cercle Linguistique de Copen. hague, 5, 1949, 7-86 (reprinted in Hamp et al.). 
and yet observes ' It is comparatively rare that the three relations of cohesion, subordination and determination should all be completely independent of one another, but an instance is provided by the combination of verb and noun in European languages'. These references to other languages were not mere glib superficial acquaintance via other people's work. He had a detailed knowledge of a wide range of languages, many of which he spoke with ease. A language he was particularly fond of was Georgian and later, when in the late sixties linguistic universals were being proposed in their strongest form, he was always likely to say 'Well, have you thought about Georgian?' But his abiding delight in languages merely served to confirm his commitment to the importance of explanation in linguistics. He himself provides an unsurpassable justification (stated within the then current assumptions of structural linguistics) for the apparent paradox in theoretical linguistics that while interested in the most exotic and the most familiar languages, linguists are not interested solely in describing those languages: ${ }^{6}$

The task of descriptive grammar is not that of describing a language structure, it is quite simply that of describing a language. A language is not necessarily to be regarded as a single structure or even as a complex of structures similar enough to be all described in the same way. It is not languages as such, but linguistic structures, which are in the centre of interest. No descriptive grammar could do justice to all the conflicting structures to be found in the language in question. Supposing that it could, what would be gained? Something very useful no doubt, but something which would have been better gained by another route: by seeking similarities of structure between parts of different languages, rather than by seeking differences of structure between parts of the same language.

While committed to the general structuralist aim of needing to establish precise terms for describing languages, ${ }^{7}$ he was ahead of his time among linguists in seeing that definitions and methodology are not the essential defining properties of a discipline, but merely a route to the explanation. Thus he argued against American structuralists that ' $A$ definition in linguistics should be merely the starting-point for classification while the fuller contours of the category are left to be filled in as the system dictates ${ }^{\prime}{ }^{8}$ and in response to their insistence on clear criteria he provides the following comment on methodology, a view rare among structural linguists: ${ }^{9}$

To seek a semantic unit within the boundaries of the word simply because these boundaries are clearer than others is like looking for a lost ball on the lawn simply because the thicket provides poor ground for a search. The sememe may have to be sought on rough ground, and by rough methods but it must be looked for where alone it can be found. This may often mean abandoning the lawn of Hjelmslev for the jungle of Jespersen, or the kindergarten of Roman Jacobson for the bear garden of Leo Spitzer. Any method (however clumsy it may appear) is welcome if it leads us nearer to the object of research.

Indeed no study of this period is complete without reading Bazell's sharplyworded 'The Correspondence Fallacy in Structural Linguistics' in which he

- Linguistic form, 105.

7 'On the problem of the morpheme', Archivum Linguisticum, 1, 1949, 1-15; 'The sememe', Litera, 1, 1954, 17-31 ; Linguistic form 1953.

' 'On the problem of the morpheme', art. cit.

- The sememe ', art. cit. 
takes every major linguist in the field to task for their varying simple-mindedness in demanding absolute and clear-cut criteria, definitions and classifications. ${ }^{10}$

It is not, however, merely or indeed principally his work in structural linguistics which explains the profound and long-lasting effect Bazell had on all research students who worked with him. It was rather his particular amalgam of an immense and active store of learning, an unlimited enthusiasm for the subject, and the unique ability to appreciate change. The range of his knowledge was unmatched among his contemporaries of the forties and fifties for he not only had a much respected background in philology and general linguistics, he also had a background and continuing interest in logic, philosophy of language, and philosophy of science. His commitment to the subject was absolute (equalled only by his other main interest-the current state of the stock market). Even informal conversation with Bazell had to take the form 'What do you think of the article in the recent issue of journal X ?'. And his idea of a pleasant social occasion was to have a quiet drink or meal with other linguists talking about linguistics. But it was above all his ability to enjoy and continue working upon an assumption of change which guaranteed his influence on students up to and beyond his retirement (his final Ph.D. student was examined shortly before his death). This up-to-the-minute ability was fostered by his reading every single journal on linguistics and on philosophy taken by the Senate House and SOAS libraries as they appeared over the months and years (he continued this journal-reading habit even after he became too weak to get into the University by going every day to the well-stocked Philosophy Library local to him at Swiss Cottage). He was thus a constant and continuing source of intellectual pleasure and stimulation to whatever graduate student had the privilege of having him as a supervisor, for he could argue in a way that was imaginative and relevant about all aspects of linguistics and philosophy of language. It was characteristic of him that he could always bring to mind often surprising literature relevant to the particular point of research. Just one example is his comment to a detail in my thesis made during 1971 ' Do you remember the Australasian Journal of Philosophy, 1958, in which .... an article and journal of which $I$ had not heard. Whether in phonology, syntax, morphology, semantics or philosophy of language, Bazell could argue about and discuss current problems and current solutions, never negatively though often critically, never cynically dismissive, always alert to why the current set of problems were of theoretical interest; and this over the period of dramatic and continuous change in the discipline caused by the work of Chomsky and then his followers. Indeed I know of no better model of Ph.D. supervision. He himself would be amazed at being set up as a pedagogical model (he was an intensely shy and private man with no pretence at either rhetorical or even normal communication talents), but I hope it would give him cause to smile. He was in my view probably the most brilliant mind London linguistics has known, but his total quite undeliberate eccentricity prevented all but the few who had the privilege of working under him from recognizing his worth.

RUTh Kempson

${ }^{10}$ In Hamp et al., 271-98. Cf. n. 4. 